\title{
Characteristics of Techirghiol Sludge and Different Methods of Peloid Therapy
}

\author{
Emin Cadar \\ "Ovidius" University of Constanta, Faculty of \\ Pharmacy, Constanta, Romania \\ Bogdan Stefan Negreanu-Pirjol \\ "Ovidius" University of Constanta, Faculty of \\ Pharmacy, Constanta, Romania \\ Ticuta Negreanu-Pirjol \\ "Ovidius" University of Constanta, Faculty of \\ Pharmacy, Constanta, Romania \\ Rodica Sîrbu \\ "Ovidius" University of Constanta, Faculty of \\ Pharmacy, Constanta, Romania
}

\section{Abstract}

The paper highlights the physical, chemical and biochemical composition of the sludge and systematizes the beneficial effects obtained by applying Techirghiol sludge through specific procedures. Techirghiol sludge is a well hydrated sapropelic sludge, with a high content of minerals and organic compounds. Following the application of sludge on the skin, a series of processes take place: stimulation of sensitive endings, energy and substance exchanges, general thermoregulation, vitamin D synthesis, regulation of homeostasis balance by immune, endocrine and neurovegetative mechanisms, better tissue oxygenation. The use of Techirghiol sludge in medical therapies is often alternative and complementary treatments in the treatment of diseases that can be good solutions for amelioration various diseases.

Keywords: sapropelic sludge, Techirghiol, sensitive endings, tissue oxygenation, general thermoregulation 


\section{Introduction}

In 2011, Techirghiol sludge was recognized by the World Federation of Hydrotherapy and Climatotherapy as the best sludge in the world. Also called "Techirghiol black gold", Techirghiol sludge has been known for 200 years for its prophylactic, healing and recovery effects. Peloid therapy (pellos, lb.Greek = shore; lb.engl. Mud-therapy, peloidotherapy) is therapy with peloids or muds, which are substances formed naturally, following geological processes, which in a finely divided state and mixed with water is used in medical practice for therapeutic purposes, in the form of local or general procedures (definition of the International Society of Medical Hydrology) [1]. The use of sludge has been done since antiquity. In ancient Egypt, people anointed themselves with the mud brought by the Nile during the floods. The Romans knew and used mud as a therapeutic agent [1]. Pliny (23-79 e.n.) recommends the use of spring sludge, Dioskorides (50 e.n.) recommends in his pharmacology the use of sludge and later Galenos (131 - 201 e.n.) indicates the use of sludge in various treatments [1]). In ancient times, Cleopatra, considered a beauty of her time, used mud for bodily maintenance for skin health. The beneficial effects of the mud and salt from the Dead Sea led her to ask Marc Antoniu to conquer this region in order to benefit from this remedy. Therefore, the use of Dead Sea mud for therapeutic purposes dates back thousands of years, from the time of the Roman Empire to the present day, without anyone complaining to this day about side effects [1].

Peloid therapy was frequently used in medieval times. Emanuel Felke, a therapist of German origin, nicknamed "Clay Pastor" tried to bring this therapy back to the modern era. In the 17th and 19th centuries, peloidotherapy became quite popular in Europe [2]. The first record of the therapeutic effects of the water of Lake Techirghiol and the mud dates from 1854, when the Ottoman commander Said Pasa made several mud baths at the instructions of the locals. Starting with the 19th century, medical research in the area will be subsidized by the Romanian state. Sapropelic sludge formed by underwater sedimentation of organic and mineral materials under the influence of biological, microbiological and physico-chemical processes, with a content of organic substances in dry mud of over $10 \%$ - exist in a continental lake, or lagoon [3]. At present, peloidotherapy is associated with other types of therapies that exist in Physical Medicine, Recovery and Balneolology (electrotherapy, physiotherapy, massage therapy, etc.), creating an individualized therapeutic plan, adapted to each patient, depending on his condition. which corresponds to a personalized medicine.

\section{General Data About Lake Techirghiol}

Lake Techirghiol, located on the shores of the Black Sea, between the localities of Techirghiol, Eforie Nord and Eforie Sud, is the largest salt lake in Romania. It has a length of 7,500 m, a maximum depth of $9 \mathrm{~m}$. This lake is fundamentally different from other lakes in its physical and geographical aspects, although the genesis is the same (fluvio-marine estuary). The average water temperature is generally close to that of 
the air. Lake Techirghiol is located S-SW of Constanta and $150 \mathrm{~m}$ away from the Black Sea. It has an irregular shape, being formed by a central basin from which start three branches: an arm directed towards the locality Techirghiol of $2 \mathrm{Km}$ long, one directed towards the village Tuzla, of $3 \mathrm{Km}$ long, and the third directed towards the village of Urlichioi of $5 \mathrm{Km}$ length (Fig. 1). The marine origin of the lake is proven, among other things, by the existence of shells of marine life, which today no longer live in the lake due to the concentration of its waters, but which continue to live in the Black Sea, such as Mitilus edulis [4]. The lake is $1.5 \mathrm{~m}$ below the level of the Black Sea, has a variable depth from $0.5 \mathrm{~m}$ to $5 \mathrm{~m}$, reaching in some places 9-10 m. It is supplied with rainwater by the rivers Techirghiol, Mazurat, Carlichioi and Celmalar and springs from Sarmatian limestones, sources not precisely identified. The lake water has a high mineralization, having a salinity of over $90 \mathrm{~g} / \mathrm{L}$.

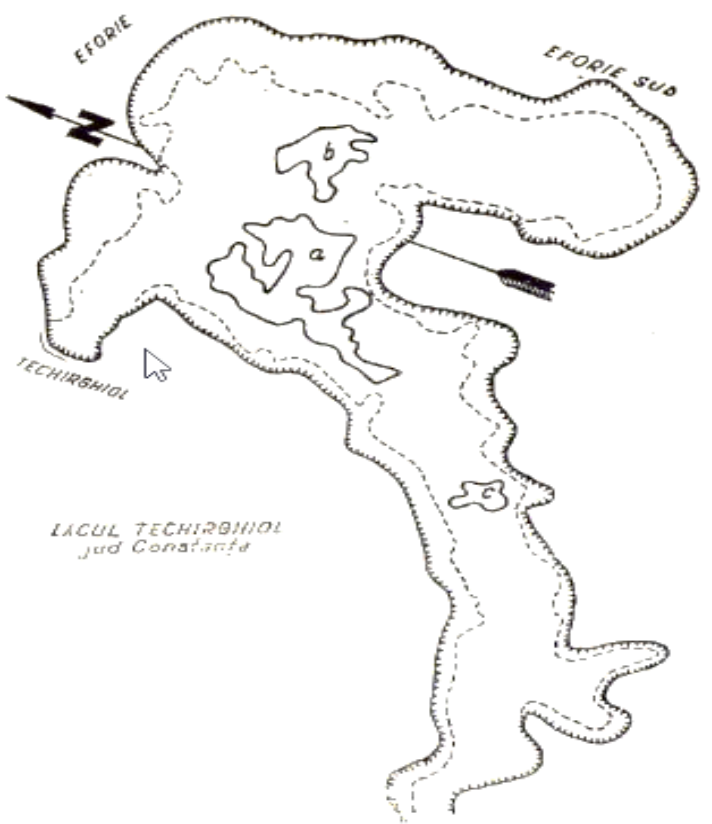

Figure 1. Techirghiol Lake map

The fauna consists of several species of arthropods, worms and protozoa, the flora through several species of algae, and towards the bottom sulfurous bacteria predominate. Lake Techirghiol is a very important avifauna area, declared a Ramsar site in 2006 (with an area of 1462 ha). Among the globally threatened bird species are the red-necked goose (Branta ruficollis) and the white-headed duck (Oxyura leucocephala).

The invertebrate fauna of Lake Techirghiol is dominated by the crustacean Artemia salina, 10-12 mm, red, (Fig.2) which together with the alga Cladophora cristalina 
provides the raw material for the production of sapropelic mud (Fig. 3). The corpses of Artemia salina, through bacterial decomposition, together with the alga Cladophora cristalina, forms the sapropelic mud [5]. Artemia salina (L.) is a primitive aquatic arthropod (salt lake) in the family Artemiidae about 100 million years old. It was discovered by Linnaeus (1758) who named it Cáncer salinus, and 61 years later, Leach (1819) renamed it Artemia salina (Asem et al., 2010). Artemia salina lives only in lakes and ponds with high salinity, which varies between 60 - 300 ppt. [1].

After identifying phytoplankton species and determining their abundance, the following types can be considered to play an important role in the productivity of these lakes with peloidogenic potential:- Filamentous algae: Cladophora crystallina, Enteromorpha clathrata, Spirogyra tenuissima, Ulotrix zonata, Rhizocloniumhieroglyphicum. These species contribute in significant quantities to the organic material of Techirghiol lakes [5].

\section{Characterization of Sapropelic Muds of Estuaries and Coastal Lakes}

The mud from Lake Techirghiol is black as oil, shiny and has a characteristic odor. Sapropelic muds are represented by black deposits rich in colloidal iron hydrosulfide, have a plastic and greasy appearance, are found on the bottom of salt waters originating from the action of microorganisms on the flora and fauna of the aquatic basin which is associated with mineral or inorganic substances.

Table 1 . The main quality indicators of sapropelic mud

\begin{tabular}{|l|l|l|}
\hline $\begin{array}{l}\text { Type of quality } \\
\text { indicators }\end{array}$ & Description \\
\hline 1 & $\begin{array}{l}\text { Macroscopic } \\
\text { properties }\end{array}$ & $\begin{array}{l}\text { Colour and physical consistency; } \\
\text { The texture of the pellets relative to the dispersion state of } \\
\text { their solid phase, } \\
\text { The size and proportion of the particles entering their } \\
\text { composition, } \\
\text { Must contain a small percentage of particles with dimensions } \\
\text { greater than 0.25 mm, estimated as the degree of dirt in the } \\
\text { mud. }\end{array}$ \\
\hline 2 & $\begin{array}{l}\text { The humidity of } \\
\text { peloids }\end{array}$ & $\begin{array}{l}\text { It is dependent on the chemical composition and their physico- } \\
\text { chemical properties, primarily colloidal. }\end{array}$ \\
\hline 3 & $\begin{array}{l}\text { Degree of hydration } \\
\text { of heterogeneous } \\
\text { peloid sediment }\end{array}$ & $\begin{array}{l}\text { The humidity in the global composition: } \\
\text {-little hydrated peloids <37\% } \\
\text {-hydrated peloids 37 - 40\% } \\
\text {-highly hydrated peloids 40 - 70\% }\end{array}$ \\
\hline 4 & $\begin{array}{l}\text { The peloidogenetic } \\
\text { stage of evolution }\end{array}$ & $\begin{array}{l}\text { Corresponding therapeutic peloid, the degree of } \\
\text { decomposition of organic substances, depending on the } \\
\text { quantitative ratio between the main classes of organic } \\
\text { substances (carbohydrates, humic substances, protein } \\
\text { substances, organic carbon / organic nitrogen) and the level of } \\
\text { biological oxygen consumption. }\end{array}$ \\
\hline
\end{tabular}




\begin{tabular}{|l|l|l|}
\hline 5 & $\begin{array}{l}\text { Overall organic } \\
\text { matter content } \\
\text { relative to dry } \\
\text { matter }\end{array}$ & $\begin{array}{l}\text { Differentiates mineral sludges from organic sludges as their } \\
\text { percentage is below or above the 10\% limit. The quantitative } \\
\text { differences between the main groups of organic substances } \\
\text { have their mark on the quality of the therapeutic sludge. }\end{array}$ \\
\hline 6 & $\begin{array}{l}\text { Mineralization and } \\
\text { ionic composition of } \\
\text { the soaking solution } \\
\text { of peloids }\end{array}$ & $\begin{array}{l}\text { As factors of interaction with the human body in the skin: } \\
\text { poorly mineralized, below 15g / L } \\
\text { mineralized, 15-35 g /L } \\
\text { strongly mineralized, 35-150 g / L } \\
\text { saturated in salts, over 150 g / L }\end{array}$ \\
\hline 7 & $\begin{array}{l}\text { Hydrogen sulphide } \\
\text { and } \\
\text { content sulphide }\end{array}$ & $\begin{array}{l}\text { In particular iron sulphide, as follows: } \\
\text { non-sulphurous peloids, below 0.02\% FeS } \\
\text { weakly sulfurous peloids, 0.02 - 0.15\% FeS } \\
\text { sulfurous peloids, over 0.15\% FeS }\end{array}$ \\
\hline 8 & $\begin{array}{l}\text { The pH of the } \\
\text { peloids }\end{array}$ & $\begin{array}{l}\text { is an indicator with a wide range of values: acids (pH below 5), } \\
\text { weakly acidic (pH between 5 and 7), weakly alkaline (pH } \\
\text { between 7 and 8 and alkaline, with pH above 8. }\end{array}$ \\
\hline
\end{tabular}

It possesses physical properties that make it extremely useful in various treatments. The sedimented mud on the bottom of the lake has an uneven distribution, being grouped in three islands of different sizes.

These islands have a stratified sludge, namely: a black therapeutic sludge, which is above a brown sludge. The brown sludge is in turn stored over a layer of gray marl. The brown mud appeared as the first deposit when the water of the lake began to separate from the water of the Black Sea, when as a result of the concentration of the waters, the fauna and flora perished massively. Shells of Mitilus edulis appear in this layer of mud, which confirms the marine origin of the lake. (3). In Table 1 was presented the main quality indicators of sapropelic mud[6]. The macroscopic properties are very important [7]. The humidity and the degree of hydration of peloids are dependent on the chemical composition. The peloidogenetic stage of evolution give information on the degree of decomposition of organic substances, depending on the quantitative ratio between the main classes of organic substances [7].

\section{The physical properties}

The physical properties of sludge are plasticity, water capacity (hydroxypexia), specific gravity, their ability to retain heat (thermopexy) and granulation are of particular importance in establishing therapeutic indications and in their use in various forms $[7,8]$.

The ionic balance of a sludge is also reflected on its $\mathrm{pH}$. In general, the sludge is alkaline $\mathrm{pH}=9-10$. The therapeutic effect of the sludge is given by the combination of its physical and chemical properties. 


\section{Chemical Composition}

From a physico-chemical point of view, sludge is a heterogeneous physico-chemical system consisting of a liquid phase containing water and water-soluble mineral salts, a solid phase containing mineral and organic substances and a gaseous phase containing hydrogen sulphide, carbide dioxide, hydrocarbons, etc. (see Figure 2.a) In Figure 2.b was presented the main compounds of Techirghiol sludge.

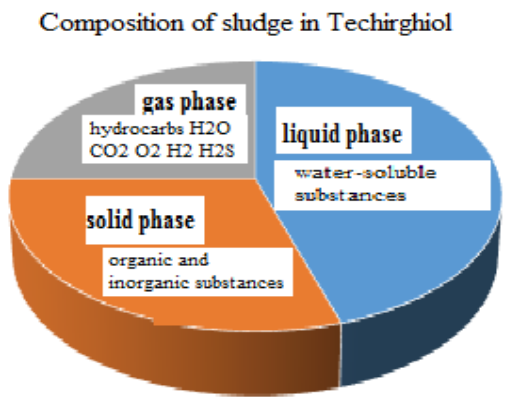

The phases of a heterogeneous sludge

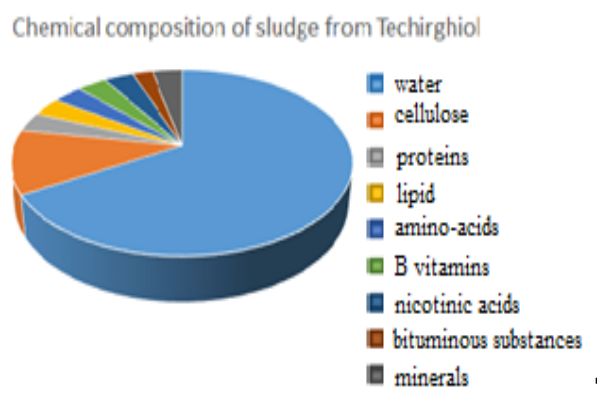

main compounds of sludge

The

Figure 2. Chemical composition of sludge in Techirghiol

Table 2. The classes of the main compounds of Techirghiol sludge

\begin{tabular}{|l|l|l|}
\hline metals & nonmetals & salts \\
\hline $\mathrm{Fe}$ & bromine & bromides \\
\hline $\mathrm{Na}$ & chlorine & clorides \\
\hline $\mathrm{Ca}$ & phosphorus & phosphates \\
\hline $\mathrm{Mg}$ & silicon & silicates \\
\hline $\mathrm{k}$ & Carbon & carbonates \\
\hline selen & sulfur & sulphates \\
\hline- & - & sulphides \\
\hline $\mathrm{Fe}$ & bromine & bromides \\
\hline
\end{tabular}

The classes of main inorgamic compounds of Techirghiol sludge was presented in Table 2. The amount of mineral substances of sapropelic sludge is $20-40 \%$.

The organic substance appears almost entirely in colloidal form, being represented by several important groups such as: carbohydrates (cellulose), lignin (hemicellulose), humic components (humic acids and humites), bituminous components (waxes, resins), lipid components and proteins and their degradation products (amino acids). Among the chemical components of the sludge, a special therapeutic importance is given to humic substances, bituminous substances, colloidal iron hydrosulfides, calcium carbonate and zeolites [4]. Humic substances, whose intimate structure has not yet been exactly specified, but whose properties, such as high degree of swelling, enzymatic braking action, ion exchange property, are 
known and represent an important physicochemical factor of sludge [4]. Zeolites have the same active participation in ion exchange (ad-and absorption). Calcium carbonate is a good skin emollient. The bituminous fraction is of interest due to the so-called estrogen-active substances it contains, highlighted by biological tests.

\section{Biological Factors of Mud}

The enzymatic activity in sludge is mainly of microbial origin, being derived from intracellular, cell-associated or free enzymes [1, 4].

Enzymes are vital activators in the body's processes, but also in sludge and play an important role in maintaining the health of the soil and its environment. These enzymes may include amylase, aryl sulfate, b-glucosidase, cellulase, chitinase, dehydrogenase, phosphatase, protease, and urease [4].

The appearance of estrogen in the aquatic environment attracts increased attention because of their strong disruptive endocrine potential. Estrogen hormones are structurally non-steroidal molecules based on the phenanthrene ring. They are produced from cholesterol primarily in the ovaries in response to signals from the brain or other organs and, albeit in smaller amounts, in the testicles of men (18). Estrogens found naturally in all classes of vertebrates are $17 \beta$-estradiol ( $\beta$-E2), $17 \alpha$ estradiol ( $\alpha$-E2), estrone (E1), and estriol (E3) [1]. Chemicals known to have the potential to bind and to activate estrogen receptors are natural compounds such as phytoestrogens, mycoestrogens and synthetic estrogen analogs, such as the potent pharmaceutical $17 \alpha$-ethynylestradiol (the active ingredient in contraceptives) [5].

A unique balance of chemical, physical and biological components (including microbial activities, especially enzymatic), contributes to maintaining the health of the sludge. The assessment of the health of the sludge therefore requires indicators of all these components. Healthy sludge is essential for the integrity of terrestrial ecosystems to remain intact or to recover from disturbances such as drought, climate change, pest infestation, pollution, and human exploitation $[4,7,8]$.

\section{Therapeutic Methods of Treatment}

Balneology and medical recovery complete the allopathic therapeutic arsenal with a wide range of natural healing factors. Therapeutic methods specific to this medical field, applied in isolation or complementary to drug treatment are indicated in a wide range of diseases, in certain stages of the disease, having a prophylactic, curative or recovery role, as addressed to the body at a certain functional stage. of the disease, during the period of convalescence or chronicity. In Table 3 we present different methods of applying peloid therapy.

The effectiveness of the spa cure depends to a large extent on establishing the optimal moment of its application, on the most appropriate choice of the resort according to the clinical profile of the individual. For this reason, the initial clinical evaluation and the recommendation of the family doctor or specialist are decisive [5]. 
In modern pathology, chronic diseases dominate, which are grafted on some functional disorders of the whole organism and which decrease its resistance capacity. In the modern orientation of therapeutics, in parallel with the specific treatment of various diseases, it is necessary to act consistently, adaptation and normalization of its functions, deranged during the pathological process $[7,8]$.

The application of therapeutic methods given by the use of sludge have a significant prophylactic character, especially for the comfort and toning of the organism, to avoid the chronicity of diseases, the avoidance of recurrences and the complications that may occur in their evolution. In Table 4 we presented the main indications for peloidotherapy $[8,10]$.

Table 3. Different methods of applying peloid therapy

\begin{tabular}{|c|c|}
\hline Type of procedure & Methods of applying peloid therapy \\
\hline $\begin{array}{l}\text { The mud } \\
\text { anointing }\end{array}$ & $\begin{array}{l}\text { it is the oldest method; involves the application of cold mud on the } \\
\text { skin in a thin layer, on limited areas or the whole body, after pre- } \\
\text { heating in the sun (10-15 minutes). The patient is then exposed to the } \\
\text { sun, in an upright position, until the mud dries ( } 30-60 \text { minutes), } \\
\text { followed by a } 10-15 \text { bath in lake or sea water, accompanied by joint } \\
\text { mobilizations in all planes and a short shower. with cold water, and } \\
\text { finally bed rest for at least an hour. }\end{array}$ \\
\hline Mud wraps & $\begin{array}{l}\text { consist of applying mud in a layer of } 1-2 \mathrm{~cm} \text { heated to } 38-46^{\circ} \mathrm{C} \text { on a } \\
\text { limited region or on the entire surface of the body, for } 20-40 \text { minutes. }\end{array}$ \\
\hline Poultices & are mud applications on limited regions of the body. \\
\hline Mud baths & $\begin{array}{l}\text { in bathtubs with heated ghiol water in which } 10-12 \text { kg of sludge are } \\
\text { added, progressively increasing its concentration up to } 10-25 \% \text {. The } \\
\text { mixture can be heated to } 44^{\circ} \mathrm{C} \text {. In patients with cardiovascular disease } \\
\text { the temperature should not exceed } 37^{\circ} \mathrm{C} \text {, and for those with } \\
\text { inflammatory rheumatic diseases }<36^{\circ} \mathrm{C} \text {. The duration of the bath is } \\
20-40 \text { minutes. The bath must be followed by a shower at } 37-38^{\circ} \mathrm{C} \\
\text { and a rest of at least one hour. A cure consists of } 12-15 \text { sessions, one } \\
\text { session per day or every two days. }\end{array}$ \\
\hline $\begin{array}{l}\text { Gynecological } \\
\text { applications }\end{array}$ & $\begin{array}{l}\text { in the form of vaginal tampons with mud at } 39-40^{\circ} \mathrm{C} \text { for } 2 \text { hours or } \\
\text { vaginal irrigation with mud dissolved in ghiol water, heated to } 37^{\circ} \mathrm{C} \text {. }\end{array}$ \\
\hline Mud massage & $\begin{array}{l}\text { involves applying mud to the skin, followed by medical massage } \\
\text { techniques. }\end{array}$ \\
\hline
\end{tabular}

Table 4. Indications for Peloid therapy

\begin{tabular}{ll}
\hline System & Diseases \\
\hline The locomotor system & inflammatory rheumatism \\
& -degenerative rheumatism with different locations: spine \\
& (spondylosis, simple discopathies, chronic lumbago, etc.), \\
& peripheral (coxarthrosis, gonarthrosis, etc.) \\
& - abarctic rheumatism \\
& - post-traumatic sequelae \\
\hline
\end{tabular}




\begin{tabular}{ll}
\hline Nervous system & - CNS and peripheral damage \\
\hline Derm & - Psoriasis - chronic eczema - chronic urticaria \\
\hline Genital system & - chronic inflammatory \\
& -secondary sterility \\
\hline Respiratory system & - ENT sphere \\
& - post-TB sequelae \\
\hline Endocrine system & - hypothyroidism \\
& - obesity \\
& - rickets or weakness in children \\
& - pituitary dwarfism \\
\hline
\end{tabular}

The main indications for peloidotherapy are rheumatic diseases, degenerative diseases such as spondylosis, osteoarthritis of the hands and feet, or inflammatory diseases such as ankylosing spondylitis. Among the diseases of the musculoskeletal system indicated for sludge therapy are other conditions such as chronic lumbago by lumbar discopathy, sequelae after disc herniation operated as well as various forms of abarticular rheumatism, tendonitis, fibrosis [11].

An important place in mud therapy is also occupied by diseases of the musculoskeletal system due to trauma, various post-traumatic sequelae, as well as neurological causes, especially neurological disorders of the peripheral nerves [10-12].

Chronic uterine-anxial gynecological diseases and infertility also occupy an important place in mud therapy, as well as a number of endocrine diseases such as hypothyroidism, hypoparathyroidism or pituitary and dermatological dwarfism such as psoriasis, eczema and chronic urticaria, etc. [12].

\section{Contraindications}

Mud therapy is contraindicated if the patient suffers from asthma, diabetes, ulcer, any form of cancer or hepatitis, if you have kidney or cardiovascular disease. Special contraindications refer to valve sequelae after acute rheumatoid arthritis, febrile forms or those with systemic manifestations or evolutionary potential marked by rheumatoid arthritis and also to febrile, disabling forms with marked kyphosis and advanced respiratory failure, forms with systemic lesions overweight ankylosing spondylitis (1).

\section{Conclusion}

Therapeutic efficiency of sludge used from the spa, Techirghiol highlighted the main conditions for which the sludge treatment is suitable, parameters that must be used for the therapeutic efficacy and the modalities of application of the sludge therapy (peloidotherapy). Among the factors used in the balneotherapy of inflammatory rheumatic diseases, the therapeutic sludge is very important. The treatment applied can have a prophylactic, curative or recovery character, depending on the variety of cases of the disease to which it is addressed. 
The treatment for prophylactic purposes will be addressed to patients who have persistent but unsystematized painful musculoskeletal syndromes.

Therapeutic treatment can be applied to patients with rheumatoid arthritis in the early stages, with inflammatory phenomena present, spondylitis, psoriatic arthropathy and arthritis secondary to gonococcal or genital infections.

The recovery treatment is addressed to patients with rheumatoid arthritis in stages II or III biologically stabilized, but with functional deficits, forms of rheumatoid arthritis who have undergone orthopedic-surgical interventions or with respiratory dysfunction.

The objectives of the cure are to reduce the pain, to fight the muscular atrophies, to increase the joint mobility, to increase the body's defence capacity, to rebalance the neuro-vegetative field.

\section{References}

[1] Chadzopulu A., Adraniotis J., Theodosopoulou - The therapeutic effects of mud -Progress in Health Sciences, Vol. 1(2), 2011, p.132-136

[2] Gheorghievici Liana M. - The contribution of the Micro- and Macrophytes to the Genesis of Therapeutic Mud from Lake Techirghiol, Romania, Balwois 2010, Ohrid Republic of Macedonia, 25, 29 May 2010.

[3] Gheorghievici Liana M., Pompei Iulia, Gheorghievici G., Tãnase I.- The influence of abiotic factors on suppliers of organic matter in the peloidogenesis process from Lake Techirghiol, Romania, AACL Bioflux, Vol.5 issue 1, 2012, p. $69-78$.

[4] Marin Viorica, Surdu Olga, Profir Daniela, Demirgian Sibel - Peloidotherapy in Osteoarthritis - Modulation of Oxidative Stress, p.143-156, published in Osteoarthritis - Diagnosis, Treatment and Surgery, Edited by Qian Chen, ISBN 978-953-51-0168-0, Hard cover, 404 pages, Publisher: InTech, Published: March 02, 2012,

[5] Marin, V., Profir, D., Roşoiu, N., Petcu, L. Evaluation of Blood Gases Pressure in Patients Treated with Sapropelic Mud of Techirghiol, Archives of the Balkan Medical Union, 2011, 45, 1, 69-74.

[6] Marin, V.; Profir, D.; Surdu, O.; Rosoiu, N. (2007), Therapeutically effects of Techirghiol sapropelic mud in oxidative stress at patients with osteoartritis, FEBS Journal, Volume 274, Supplement 1, Julay 2007, pp.1378, 32nd FEBS Congress, Molecular Machines, Vienna, Austria, C4-76, 213.

[7] Munteanu C., Terapeutic Mud, Editura Balneară, Buc. 2012, 7-10

[8] Munteanu, C., Cintezã Delia - Cercetarea ştiințificã a factorilor naturali terapeutici, Editura Balneara, ISBN 978-606-92826-8-7, 2011

[9] Munteanu, C., Dumitraşcu Mioara - Nãmoluri terapeutice, Balneo-Research Journal, Vol.2 (3), 2011, Editura Balneara, ISSN 2069-7600 
[10] Surdu Olga Studiu histologic comparativ al acţiunii nămolului sapropelic de Techirghiol asupra tegumentului. Universitatea Ovidus Constanţa, Facultatea de Medicinã, Generalã, Teză de doctorat, 2007.

[11] Surdu, O. Evaluarea factorului chimic de actiune al nămolului sapropelic de Techirghiol, 18-19, ISBN 978-973-591-520-9, Ed. Gramar, Bucureşti, 2006.

[12] Teleki N., Munteanu L., Bibicioiu S.- România Balneara, Ghid pentru medicii de familie şi pentru medicii specialişti, București. 2004. 